\title{
Significance of Social Media in Information System Planning: A Survey
}

\author{
Ms. Komal ${ }^{1}$ \\ ${ }^{I}$ Department of Computer Science \& Engineering, Amity University Haryana, Gurgaon, Indiia \\ Email: komal@ggn.amity.edu
}

\begin{abstract}
In a period where innovation and advancement wins, business visionaries and furthermore advertising specialists see the need to remain mindful of the fast pace of advancement or risk being out of date. Gone are the days when an unadulterated squares plan of activity will prosper well in current market circumstance. It is essentially hard to layout an Information System (IS) planning without considering social networking. Internet based life and social media prevalence have significant impact on communication channels between organizations and existing as well as potential customers. The paper discusses an observational research to grasp the reasonability of social media as an elevating instrument to conventional Information System of an organization. The paper presents a comparative study of Information system approaches of two service based industries with due consideration to social media presence.
\end{abstract}

Index Terms-Information System, Social media marketing, CRM, strategic business planning.

\section{INTRODUCTION}

In today's world, social media and networking has turned out to be universal and most critical for creating friend zones, interpersonal communication, content sharing and making associations. Because of its unwavering quality, consistency and quick highlights, internet based life opens a wide place for organizations. Promoting products and services through online networking is known as social media marketing.

Social media has influenced organizations to reach to target buyers effortlessly, successfully and immediately. In the course of recent years, we have encountered a radical move in how business is led and how individuals communicate. The presentation of social media innovation is quickening and we can anticipate that it will similarly affect organizations presently and into what's to come. As new innovations ended up accessible, organizations that figure out how to utilize new innovations boost their profits.

A portion of the best-known illustrations incorporate innovation driven organizations, for example, Microsoft, eBay, Amazon and Google. In a limited ability to focus time, online networking has turned out to be a standout amongst the most cherished mediums for the youth today. Destinations like Face book, Twitter, LinkedIn are affecting the way clients build up, keep up and develop a scope of social connections, from dear kinships to easy going colleagues. Customers today need to be more educated about items previously bought by other customers. Most imperatively, social media platforms are to a great degree fit for educating and affecting buy choices, the same number of clients presently believes their associate assessments more than the showcasing strategists. Clients currently have the ability to argue at the brand and communicate their sentiments of the mark. Along these lines, advertisers must choose the option to treat them contrastingly and with more noteworthy regard.

The phases and tasks of Information System planning strategy represent the components of the planning process, with each having its own objectives, participants, preconditions, products, and techniques. The phases and tasks can be used to describe an organization's attempts to be comprehensive in its strategic planning process (Newkirk 2013). SISP unfolds in five phases. The overall five phase breakdown is as follows (Pollack 2010):

1) Strategic Business Planning: Prerequisite to systems planning. It outlines an organization's overall direction, philosophy, and purpose. It examines its current status in terms of its strengths, weakness, opportunities, and threats. It sets longterm objectives. It formulates short-term tactics to reach them.

2) Information Systems Assessment: Evaluation of the system to assess its status in terms of original or current expectations and how they are serving the organization.

3) Information Systems Vision: Ideal role that should be pursued for use of information systems resources. 4) Information Systems Guidelines: Set of statements that clarify use of organization's technical and information systems resources

5) Strategic Initiatives: Three to five year long-term proposals that specify new initiatives for information systems organization. SISP process can be summarized graphically.

\section{LITERATURE ANALYSIS}

\subsection{Elements of Social Media Marketing}

Social media marketing strategy has some essential elements which every organization must take into account (Daoud, 2016). All these steps have been clearly represented in the fig. 1 . 
International Journal of Research in Advent Technology, Vol.7, No.5, May 2019

E-ISSN: 2321-9637

Available online at www.ijrat.org

- Improved Search Engine Rankings - Social Media allows communicating the business content out to an extensive variety of intrigued readers. Interested candidates at that point visit your web content, enquire, tell their companions, and at last

- connect to it. Google and Bing both focus on social signs this way and they rank connections on the query items page (CHHEDA, 2014).

- Enhanced Customer Service- Clients utilizing one of the regular stages like Facebook or Twitter can without much of a stretch convey specifically and snappy response to them in an open arrangement gives different clients a chance to see your responsiveness.

\subsection{Benefits of using Social Media in IS}

- Cost-effectiveness- that one can get the best blast for your promoting (CHHEDA, 2014).

- Global Reach- Social Media knows no boundary; it is a cross-country marketing strategy with no additional efforts.

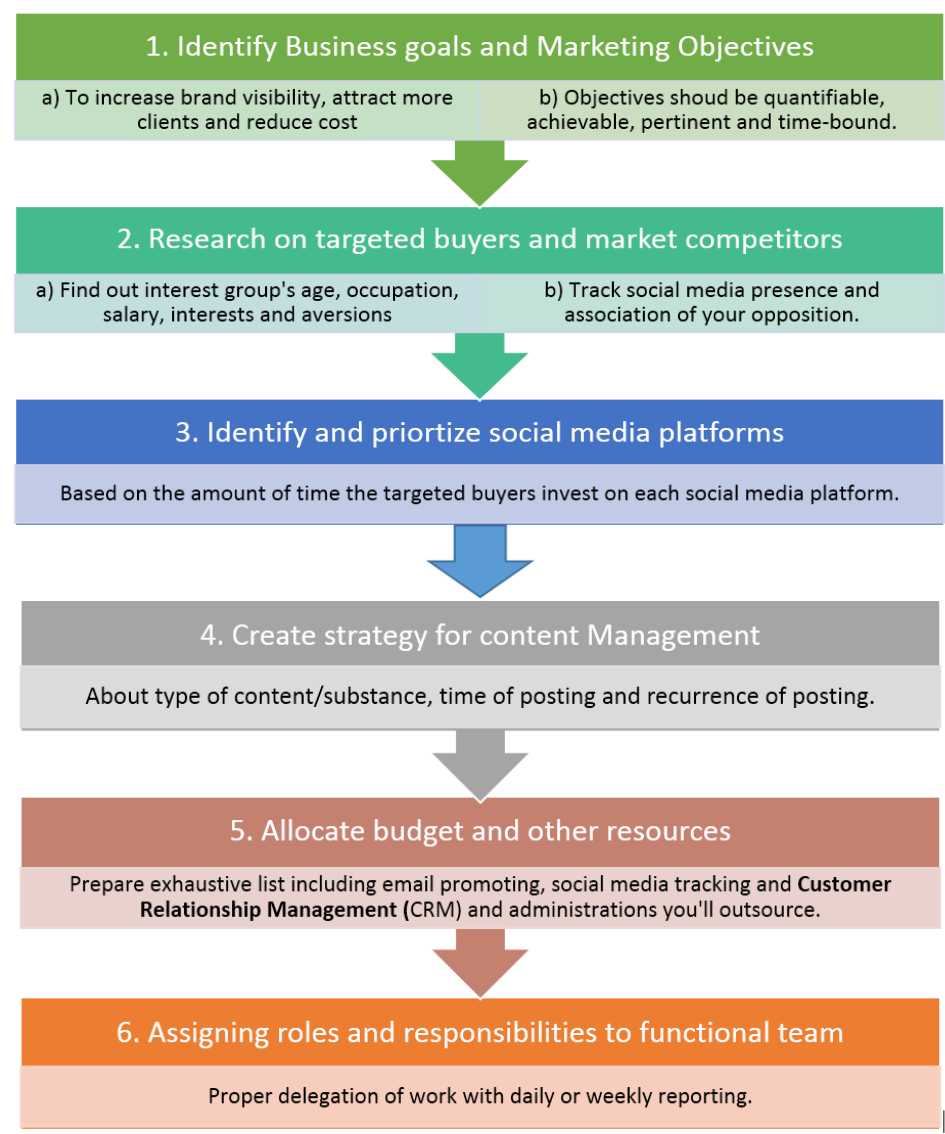

- Better Consumer connect- It is an awesome method to show your business identity, your representatives, your workspace, behind the scene stories and consumer experiences.

- New B2B Connections- From conceivable vital business accomplices to new wholesalers, web based life lets have genuine discussions with real individuals who may some way or another is socially or geologically difficult to reach in reality.
- Targeted Audience- Social media furnish advertisers with the capacity to target gatherings of people and buyers in view of website clients' close to home interests and what their companions like.

- Competitive Advantage-In the event that utilized accurately, web-based social networking can help our pursuit rankings, permit to give better client benefit, manufacture a successful online identity, associate with new business accomplices, assemble 
International Journal of Research in Advent Technology, Vol.7, No.5, May 2019

E-ISSN: 2321-9637

Available online at www.ijrat.org

- $\quad$ associations, and approve proficient standing all while giving shoppers the esteem they need (Rubathee Nadaraja, 2013).

- Validating business identity - When a customer ask questions or provide feedback on a common platform like social media page, where these queries and suggestions are responded well from the organizations/brand side. This validates business identity as people tend to believe them easily (Rubathee Nadaraja, 2013).

- Creates Value for business-The possibility that we can give a really significant support of our objective market implies we are situating ourselves as a specialist in the business. Regardless of whether that is instructive and engaging online journals, posts, or tweets, in the event that we are taking care of an issue or giving data, we're including esteem that clients will appreciate.

\subsection{Challenges of IS integrated with Social Media}

The online condition makes openings, as well as challenges and difficulties for the process of social media marketing (Paliwal, 2015)

- Time demanding - It is quite time-consuming to showcase identity on social media, with the attention set on setting up long haul connections that can transform into more deals. One or more persons must be mindful to screen each system, react to remarks, answer inquiries and post item data the client considers significant.

- Copyright and trademark Issues -Regardless of means whether by an outsider outlet or a company's own identity, advertisers ought to routinely screen the utilization of their trademarks and copyrights. Organizations should screen their own social media platform and third-party services to guarantee that those giving substance through the media outlets are not abusing their protected innovation.

- Brand health and negative inputs - Buyers post item surveys, pictures, and labels, which fill in as an important wellspring of data for clients settling on item decisions on the web. They can also post negative feedback regarding organization, its items, and its administrations, depending both on how the organization is introduced on the web and on the nature of items.

- $\quad$ Product pricing strategy-Once the advertiser has broke down the market and decided target fragments, he or she should then build up an advertising that adjusts nearly to the wants of the objective portions. (Pondichery, 2014).

- Automated interactions- It endangers consumer loyalty and brand wellbeing. All the more particularly, relocating clients to online channels may make opposition and client disappointment, as clients may feel compelled to utilize new channels (Peter S.H. Leeflang, 2013).
- Price Transparency-The expanding price transparency has been a subject of examination since the beginning of Internet, and scientists have explored price contrasts amongst disconnected and online retailers. Surprisingly, firms so far don't consider the nearness of an expanding value straightforwardness as a vital test. Particularly in the current tight monetary circumstances, clients feel a much more grounded strain to locate a decent offer (Peter S.H. Leeflang, 2013).

- $\quad$ Shift in marketing skill set- While verbal content mining has turned out to be basic in the showcase writing, the billions of visual pictures transferred are an undiscovered asset for advertisers. specific programming skills needs to be used for content information preparing utilizing semantic and syntactic learning (C.F.Hofacker, 2016).

\section{TOOLS FOR SOCIAL MEDIA BASED INFORMATION SYSTEM PLANNING}

Companies do their best to remain over the most recent advancements in social media promotions; however there are new stages and advances built up each day. Following tools help a great deal in making social media marketing successful (Blacklabel, 2018).

- Buffer: This web based life administration application sits at the highest point of numerous rundowns and all things considered. You can work with different online networking profiles from a solitary board, plan posts ahead of time and monitor your investigation. Some outsider applications offer Buffer help, which settles on it a decent decision to add to your promoting stack.

- ManageFlitter: Managing Twitter physically makes it troublesome, if certainly feasible, to get an incentive out of the stage. ManageFlitter has some cover with Buffer, for example, planned posting and investigation. It enables you to recognize influencers and achieve a greater amount of your devotees.

- Canva: Social media refreshes with visual substance draw in more consideration than content alone, however getting your visual creators to make pieces for each and every refresh may not be practical. Canva is an easy to understand visual computerization programming that offers formats, outline components and an intuitive interface that streamlines the whole process.

- HootSuite Insights: HootSuite Insights is a vigorous social listening instrument that separates itself with finish constant investigation. The social supposition highlight demonstrates you whether individuals feel positive, negative or impartial about your image. This application covers the standard internet 
International Journal of Research in Advent Technology, Vol.7, No.5, May 2019

E-ISSN: 2321-9637

Available online at www.ijrat.org

based life channels yet additionally makes it one stride further to filter discussions, blog entries and different sites. In the event that somebody is discussing your image on the web, this application will tell you.

\section{SECURITY CONTROLS FOR SOCIAL MEDIA ORIENTED INFORMATION SYSTEM PLANNING}

Web-based social networking can represent various dangers to the associations and people when utilized as a part of an improper or dangerous way. The utilization of web based life for business purposes ought to be administered by associations' social media usage policies. The accompanying measures ought to be actualized for corporate web based life accounts (Centre, 2018).

- Allow legitimate clients to approach organization's social media accounts.

- Ensure that clients are educated of, and consent to, social media utilization approaches.

- Make sure that clients know about what can, and can't, be posted utilizing corporate internet based life accounts.

- Make sure that clients know about procedures for reacting to posting of delicate or improper data.

- Make sure that clients know about procedures for recapturing control of commandeered corporate social media accounts.

\section{CASE STUDIES}

To identify the impact and role of social media marketing in Information System planning, a survey has been conducted for two companies (whose name is kept anonymous in the paper). The comparative assessment is as shown in table below:

Table 1. Comparison of IS Strategies of two servicebased companies

\begin{tabular}{|c|c|c|}
\hline Decisive factor & Company A & Company B \\
\hline $\begin{array}{l}\text { Product-based } \\
\text { /Service-based }\end{array}$ & $\begin{array}{l}\text { Service- } \\
\text { based } \\
\text { (Internet } \\
\text { Service } \\
\text { provider) }\end{array}$ & $\begin{array}{l}\text { Service-based } \\
\text { (provides } \\
\text { commercial } \\
\text { relocations ) }\end{array}$ \\
\hline
\end{tabular}

\begin{tabular}{|c|c|c|}
\hline $\begin{array}{l}\text { Monitoring } \\
\text { activities }\end{array}$ & $\begin{array}{l}\text { Project } \\
\text { reports } \\
\text { extracted } \\
\text { and } \\
\text { reviewed } \\
\text { with team }\end{array}$ & $\begin{array}{l}\text { Review } \\
\text { meeting, } \\
\text { Status reports, } \\
\text { Scrum calls }\end{array}$ \\
\hline $\begin{array}{l}\text { Assessment of IS } \\
\text { architecture }\end{array}$ & $\begin{array}{l}\text { On yearly } \\
\text { basis }\end{array}$ & $\begin{array}{r}\text { On } \quad \text { yearly } \\
\text { basis }\end{array}$ \\
\hline $\begin{array}{l}\text { Evaluating } \\
\text { Success of IS } \\
\text { plan }\end{array}$ & $\begin{array}{l}\text { Based on } \\
\text { customer } \\
\text { feedback }\end{array}$ & $\begin{array}{l}\text { Through } \\
\text { customer } \\
\text { criticism and } \\
\text { reactions }\end{array}$ \\
\hline $\begin{array}{l}\text { Association } \\
\text { between IS plan } \\
\text { and social media } \\
\text { plan }\end{array}$ & $\begin{array}{l}\text { Both are } \\
\text { closely } \\
\text { associated }\end{array}$ & $\begin{array}{l}\text { Very close } \\
\text { association } \\
\text { between IS } \\
\text { and social } \\
\text { media plans } \\
\end{array}$ \\
\hline $\begin{array}{l}\text { Decision about } \\
\text { long-term or } \\
\text { flexible } \\
\text { solution/system }\end{array}$ & $\begin{array}{l}\text { Flexible } \\
\text { (decided as } \\
\text { per } \\
\text { marketing } \\
\text { needs) }\end{array}$ & $\begin{array}{l}\text { Discussed with } \\
\text { VP level heads }\end{array}$ \\
\hline $\begin{array}{l}\text { Security controls } \\
\text { of Social media }\end{array}$ & $\begin{array}{l}\text { Third-party } \\
\text { maintenance } \\
\text { Closely } \\
\text { monitored }\end{array}$ & $\begin{array}{l}\text { Layers of } \\
\text { security } \\
\text { deployed with } \\
\text { authoritative } \\
\text { and } \\
\text { authentication } \\
\text { features }\end{array}$ \\
\hline
\end{tabular}

\section{CONCLUSION}

It is time for the organizations to make use of compelling techniques and implement them to gain a big share of market for potential clients and customers. It is more critical than ever that the organizations utilize social media Engagement and Advertising standards to anticipate effectively their prospects about captivating clients. However, the customers do not see internet based life and social media pages of various brands as a means to address their grievances. The core reason behind it is slow or no response of brands to the issues raised by the customers. So, in order to impact your prospects and clients, your business exertion must take after a 
International Journal of Research in Advent Technology, Vol.7, No.5, May 2019

E-ISSN: 2321-9637

Available online at www.ijrat.org

procedure to deal with the grievances of customers through social media channels which have an astounding capacity to lead your prospects and clients to profitable substance situated on your website.

\section{REFERENCES}

[1] Pollack T. A. (2010): Strategic Information Systems Planning. Proceedings of the ASCUE, pp.112-135.

[2] Newkirk H.E., Lederer A.L., Srinivasan C. (2013): Strategic information systems planning: too little or too much. Journal of Strategic Information Systems, 12(3), pp. 201- 228.

[3] Daoud, H. (2016): 8 Essential Elements of a Social Media Marketing Strategy. [Online] Availableat:https://www.socialmediaexaminer.c om/essential-elements-social-media-marketingstrategy/[Accessed 5 June 2018].

[4] Rubathee Nadaraja, R. Y. (2013): Social Media Marketing: Advantages And Disadvantages. Social Media Marketing, pp. 1-10.

[5] Chheda, S. H., 2014. Impact Of Social Media Marketing On Performance Of Micro And Small Businesses, Navi Mumbai: M.Phil Dissertation.

[6] Paliwal, G., 2015. Social media marketing : opportunities and challenges, Massachusetts: Massachusetts Institute of Technology.

[7] Pondichery, S. K., 2014. All about Problems and Challenges in Social Marketing. International Journal of Innovation and Scientific Research, 3(1), p. 40-46.

[8] Peter S.H. Leeflang, P. C. V. P. D. T. F., 2013. Challenges and solutions for marketing in a digital era. European Management Journal, 32(2014), pp. 1-12.

[9] C.F.Hofacker, D., 2016. Eight social media challenges for marketing managersOcho retos de los medios sociales para los Directores de Marketing. Spanish Journal of Marketing ESIC, 20(2), pp. 73-80.

[10]Blacklabel, 2018. Social Media Marketing Technology: Our 10 Favorite Tools. [Online] Availableat:https://blacklabelagency.com/socialmedia-marketing-technology-our-10-favoritetools/[Accessed 4 June 2018].

[11]Centre, A. C. S., 2018. SECURITY AND SAFETY TIPS FOR SOCIAL MEDIA. [Online] Availableat:https://www.asd.gov.au/publications /protect/using-social-media.htm [Accessed 5 June 2018]. 